\title{
СИНТЕЗ И ИЗУЧЕНИЕ БИОЛОГИЧЕСКОЙ АКТИВНОСТИ НОВЫХ ПРОИЗВОДНЫХ 3,7-ДИАЗАБИЦИКЛОНОНАНА
}

\author{
М. Салыкина, Е. Безсонова, А. Ефремов \\ Химический факультет, МГУ им. М.В. Ломоносова, \\ 119991, Россия, Москва, Ленинские горы, д.1.
}

DOI: 10.19163/MedChemRussia2021-2021-397

E-mail: salykina_99@mail.ru

Структура 3,7-диазабицикло[3.3.1]нонана является легкодоступным скаффолдом для конструирования конформационно ограниченных структур с разнообразной биологической активностью. Так, подобные структуры являются эффективными модуляторами АМРА-рецепторов [1], а также могут служить исходными соединениями для синтеза миметиков природных противораковых структур [2]. Нами впервые проведен синтез производных 3,7-диазабицикло[3.3.1]нонана, содержащих фторные, метильные и карбоксильные группы. Также была изучена биологическая активность данных соединений.

Было проведено бромирование исходных соединений, нуклеофильное замещение цианидом калия. Последующий гидролиз нитрилов привел к получению производных фенилуксусной кислоты, которые затем ввели в реакцию кетонизации кальциевых солей карбоновых кислот. Полученные по реакции Манниха кетоны ацилировали хлорангидридами кислот. Проводили восстановление кетонов с помощью $\mathrm{LiAlH}_{4}$ с последующим раскрытием цикла хлорангидридами карбоновых кислот.

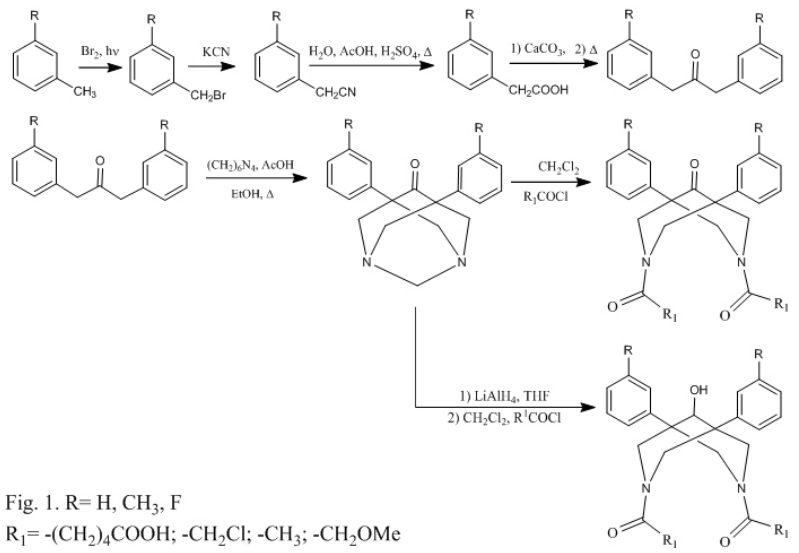

Работа выполнена при финансовой поддержке РФФИ проект 20-03-00915.

\section{References}

[1] M.Lavrov, S.Karlov, et al.., Mol. Neurobiol. 2020, 57, 191-199.

[2] S.Sosonyuk, et al. Org. Biomol. Chem., 2019, 56, 915-922. 